\title{
QUALITY OF DIGESTATE FROM ANAEROBIC DIGESTION OF WETLAND BIOMASS
}

\author{
Slawomir Roj-Rojewski, Agnieszka Wysocka-Czubaszek, Robert Czubaszek, Piotr Banaszuk \\ Bialystok University of Technology, Poland \\ s.roj@pb.edu.pl,a.wysocka@pb.edu.pl,r.czubaszek@pb.edu.pl, p.banaszuk@pb.edu.pl
}

\begin{abstract}
Although the biomass from nature conservation management is gaining particular attention as a supplement or even substitute to energy crops, there is still little research on the production of biogas from wetland biomass and the quality of digestate obtained in anaerobic digestion. This study aimed to analyse selected physical and chemical properties of residues from anaerobically digested biomass harvested in a fluviogenous mire in a context of suitability as an agricultural fertilizer. We conducted a biomethane potential assay of five wetland plants: reed canary grass (Phalaris arundinacea), common reed (Phragmites australis), reed sweet-grass (Glyceria maxima), tufted sedge (Carex elata) and woollyfruit sedge (Carex lasiocarpa), cut in three different seasons of the year. Obtained digestates characterized a higher content of organic matter (75.1$82.4 \% \mathrm{TS})$ and electrical conductivity $\left(12.9-18.8 \mathrm{mS} \cdot \mathrm{cm}^{-1}\right)$ compared to the residues from a conventional agricultural biogas plant, treating mainly maize silage. They had, however, lower $\mathrm{pH}$ (7.4-7.8) and content of total phosphorus (0.7-1.2\% TS), while total nitrogen and potassium contents were similar $(2.8-6.2 \%$ TS and 4.3-6.1\% TS, respectively). Significant differences were found between digestates from different species of wetland plants. Although the term of biomass harvest had the impact on the physical and chemical properties of the digestates, each of the analysed $\mathrm{AD}$ products was found to be valuable sources of nutrients and organic matter and possessed a high potential as agricultural fertilizers.
\end{abstract}

Keywords: anaerobic digestion, wetland biomass, digestate, agricultural fertilizer.

\section{Introduction}

Agricultural biomass is a significant substrate in European biogas plants. In Poland, the substrates for biogas production are most often sludge from sewage treatment plants, municipal waste and food industry waste [1]. The energy potential of agriculture in Poland indicates the possibility of the production up to 6 billion $\mathrm{m}^{3}$ of biogas per year, including biomass from permanent grasslands alone giving up to 1.7 billion $\mathrm{m}^{3}$ without detriment to the supply of forage [2]. Despite considerable biomass resources, their use for the biogas production in Poland is still low.

In most of the agricultural biogas plants, biogas is generated by the co-fermentation of energy crops mixed with liquid manure or water. Maize silage has dominated the agricultural biogas market in Europe [3], and in Poland [1;2].

An exciting alternative to maize for agricultural biogas plants may provide wetland biomass, which use for energy generation was proved to be more environmental and social friendly compared to energy crops. A substantial amount of Phragmites australis, Phalaris arundinacea, and Carex sp. is harvested annually in Poland as a part of wetland conservation programs [4]. Studies so far, which are few, indicate that wetland biomass could be a good co-substrate in agricultural biogas plants, with methane productivity that is comparable to swine manure [5]. There is also little research on the quality of digestate obtained in anaerobic digestion from wetland plants.

The composition and quality of the feedstock affect to a great extent the composition and quality of digestate [6]. Generally digestate has a lower total solids (TS) and total organic carbon (TOC) content, lower carbon to nitrogen ratio $(\mathrm{C}: \mathrm{N})$, but higher $\mathrm{pH}$ value and the share of ammonium compared to raw animal manures and slurries [7-10]. Digestate has a lower dry matter content than the undigested influent, because at least $50 \%$ of total solids content is converted to methane and carbon dioxide [7; 11].

Because of the content of easily plant available macro- and micronutrients, especially nitrogen $(\mathrm{N})$, phosphorus $(\mathrm{P})$, potassium $(\mathrm{K})$, various microelements and organic matter, the digestate is treated as a valuable crop fertilizer. Its recycling as fertilizer is considered to be the most sustainable utilization of digestate $[6 ; 12]$.

The aim of the present study was to select physical and chemical properties of residues from anaerobically digested biomass harvested in fluviogenous mire in a context of suitability as an agricultural fertilizer. We conducted a biomethane potential assay of five wetland plants: reed canary grass (Phalaris arundinacea), common reed (Phragmites australis), reed sweet-grass (Glyceria 
maxima), tufted sedge (Carex elata) and woollyfruit sedge (Carex lasiocarpa), cut in three different seasons of the year.

\section{Materials and methods}

In biomethane potential (BMP) assay we used biomass of common wetland plants: reed canary grass (Phalaris arundinacea L.), common reed (Phragmites australis (Cav.) Trin. ex Steud), reed sweet-grass (Glyceria maxima (Hartm.) Holmb.), tufted sedge (Carex elata All.) and woollyfruit sedge (Carex lasiocarpa Ehrh.) [5]. They were collected from the mown part of the Narew River Valley within the border of the Narew National Park, Poland, three times in the year 2015: July 22 (midsummer), August 28 (late summer) October 8 (early fall). The homogenous plant material was dried at the room temperature for $24 \mathrm{~h}$ and then cut, compressed and wrapped in three layers of polyethylene stretch-film. Small squared bales of ca. 0.5-1.0 kg each were prepared for the experiment and were open in the day of the experiment start-up. The ensiled plants were cut into particles of ca. $2 \mathrm{~cm}$ with scissors. Inoculum for biomethane potential assays was obtained from a post digestion tank of mesophilic biogas plant treating maize silage with addition of ca. $15 \%$ of swine manure and ca. $5 \%$ of chicken droppings located in Ryboły, NE Poland. It was taken as two independent samples at different time periods. In this study, the inoculum was treated as a typical agricultural biogas plant digestate and used in every statistical comparison.

BMP tests were conducted using OxiTop Control System OC 110® (WTW, Germany) in triplicate in $1 \mathrm{~L}$ glass bottles with working volume of $400 \mathrm{~mL}$ at the temperature $37 \pm 1^{\circ} \mathrm{C}$ in a thermostatic incubator. Distilled water was added to reach the working volume. No $\mathrm{pH}$ adjustment was made. Ratio VSinoculum to VSsubstrate was 1:1, according to Seppälä et al. [13]. TS of mixtures in bottles was around $8 \%$, which is the minimum of typical total solids content of the digester of most biogas plants [14]. The batches have been incubated for 35 days. Each bottle was mixed manually once a day. For daily measurements of the biogas content the batch experiment in eudiometers on the same conditions like in OxiTops was performed. In this study, only the results of chemical and physical properties of digestates from OxiTop experiment were shown. Partly, biogas and methane production from wetland plants was included in the previous publication of the authors [5].

The total solids (TS) and volatile solids (VS) were determined in triplicate according to standard methods [15], $\mathrm{pH}$ in $\mathrm{H}_{2} \mathrm{O}$ and EC was measured with HQD40 (Hach, USA). Total carbon (TC) was determined in a TOC-L analyser (Shimadzu, Japan), total Kjeldahl nitrogen (TKN) was determined by the Kjeldahl method in the Vapodest 50s analyser (Gerhardt, Germany). Total phosphorus (TP) was measured with the ammonium metavanadate method using the spectrophotometer UV-1800 (Shimadzu, Japan), total potassium (TK) was measured with the flame photometer (BWB Technologies, USA).

Differences in chemical and physical properties of digestates from studied wetland plants were analysed using the generalized linear mixed models procedure (GLIMMIX) in SAS, Version 9.4 (SAS Inst., Cary, NC), with repeated measures as a split-plot design. The main plot was the harvest date and subplot was plant species (fixed effects). Repeated measurements (replications) were used as a random effect. Tukey-Kramer analyses were performed for multiple comparisons.

Differences between wetland plant digestates (5 species, 3 harvest seasons) and agricultural biogas plant digestate were also calculated using GLIMMIX in SAS, but this time with repeated measures as a randomized complete block design (RCBD) and Tukey-Kramer tests for multiple comparisons. Statistica 13.1 was used for creating box and whiskers plots and performing comparisons for two samples. For this purpose, we used t-Student tests or Mann-Whitney tests, depending on the fulfilment of the appropriate conditions. In all tests the accepted statistical significance was $p<0.05$.

\section{Results and discussion}

Chemical and physical properties were determined in digestates after BMP tests of 5 wetland plants (Table 1). The average TS content amounted $7.1 \% \mathrm{ww}$ and ranged between 6.1 and $9.1 \% \mathrm{ww}$, while VS varied from 75.1 to $82.4 \%$ TS (mean $79.2 \%$ TS). The $\mathrm{pH}$ of all digestates was similar and changed in a narrow range between 7.4 and 7.8 (mean 7.6). Greater variability was observed for EC (range 12.9-18.8 mS $\mathrm{cm}^{-1}$, mean $16.8 \mathrm{mS} \cdot \mathrm{cm}^{-1}$ ). TC content varied from $37.2 \%$ TS to $42.7 \%$ TS (mean $40.3 \% \mathrm{TS}$ ), and TKN content varied from $2.8 \%$ TS to $6.2 \%$ TS (mean $4.3 \%$ TS). C:N ratio 
ranged between 6.9 and 13.7 (mean 10.0). The TP content reached values from 0.7 to $1.2 \%$ TS (mean $0.9 \%$ TS) and TK content - from 4.3 to $6.1 \%$ TS (mean $5.2 \%$ TS).

Table 1

Mean $(n=3)$ chemical and physical properties of studied digestates

\begin{tabular}{|c|c|c|c|c|c|c|c|c|c|c|}
\hline Digestate & $\begin{array}{c}\text { Har- } \\
\text { vest }\end{array}$ & $\begin{array}{c}\text { TS } \\
\% \text { ww }\end{array}$ & $\begin{array}{c}\mathbf{V S} \\
\% \mathrm{TS}\end{array}$ & pH & $\begin{array}{c}\text { EC } \\
\mathrm{mS} \cdot \mathrm{cm}^{-1}\end{array}$ & $\begin{array}{c}\mathbf{T C} \\
\% \mathrm{TS}\end{array}$ & $\begin{array}{l}\text { TKN } \\
\% \text { TS }\end{array}$ & C:N & $\begin{array}{c}\mathbf{T P} \\
\% \mathrm{TS}\end{array}$ & $\begin{array}{c}\text { TK } \\
\% \text { TS }\end{array}$ \\
\hline \multirow[t]{3}{*}{ RSG } & MS & 6.6 & 80.6 & 7.4 & 17.0 & 41.7 & 5.4 & 7.7 & 0.9 & 4.9 \\
\hline & LS & 6.2 & 79.4 & 7.5 & 17.7 & 38.3 & 3.2 & 11.8 & 0.7 & 5.4 \\
\hline & $\mathrm{EF}$ & 6.5 & 75.1 & 7.7 & 16.5 & 42.6 & 6.2 & 6.9 & 1.1 & 6.0 \\
\hline \multirow[t]{3}{*}{$\mathrm{CR}$} & MS & 6.7 & 79.7 & 7.6 & 18.3 & 41.9 & 4.6 & 9.2 & 0.9 & 5.8 \\
\hline & LS & 7.3 & 76.6 & 7.7 & 18.8 & 37.2 & 2.9 & 13.1 & 0.7 & 5.0 \\
\hline & $\mathrm{EF}$ & 9.1 & 76.1 & 7.7 & 17.4 & 39.3 & 4.0 & 10.1 & 1.0 & 5.2 \\
\hline \multirow[t]{3}{*}{ RCG } & MS & 6.1 & 78.4 & 7.8 & 17.8 & 40.3 & 5.4 & 7.5 & 1.0 & 5.5 \\
\hline & LS & 6.3 & 78.5 & 7.8 & 18.1 & 39.2 & 3.3 & 11.8 & 0.8 & 4.9 \\
\hline & $\mathrm{EF}$ & 8.6 & 77.0 & 7.8 & 15.8 & 37.7 & 5.2 & 7.2 & 1.0 & 5.0 \\
\hline \multirow[t]{3}{*}{$\mathrm{TS}$} & $\mathrm{MS}$ & 6.7 & 82.4 & 7.5 & 14.9 & 42.7 & 4.4 & 9.6 & 1.0 & 5.2 \\
\hline & LS & 6.9 & 79.6 & 7.6 & 18.6 & 38.5 & 2.8 & 13.7 & 0.8 & 6.1 \\
\hline & $\mathrm{EF}$ & 8.1 & 80.3 & 7.6 & 12.9 & 41.4 & 4.6 & 9.0 & 1.2 & 4.3 \\
\hline \multirow[t]{3}{*}{ WS } & MS & 6.7 & 80.6 & 7.7 & 17.8 & 40.8 & 4.1 & 9.9 & 0.8 & 6.0 \\
\hline & LS & 7.0 & 81.6 & 7.6 & 17.2 & 40.4 & 3.0 & 13.7 & 0.7 & 4.7 \\
\hline & $\mathrm{EF}$ & 7.7 & 81.5 & 7.6 & 13.8 & 42.1 & 4.6 & 9.1 & 0.7 & 4.6 \\
\hline Factors & & $p>F$ & $p>F$ & $p>F$ & $p>F$ & $p>F$ & $p>F$ & $p>F$ & $p>F$ & $p>F$ \\
\hline Harvest & & $0.0005^{*}$ & $0.0187^{*}$ & 0.2723 & $0.0078^{*}$ & $0.0116^{*}$ & $0.0003 *$ & $0.0004 *$ & 0.0046* & 0.2047 \\
\hline Species & & $0.0007^{*}$ & $0.0007^{*}$ & $0.0328 *$ & $0.0128 *$ & $0.0034 *$ & $0.0008^{*}$ & $0.0045^{*}$ & $0.0026^{*}$ & \begin{tabular}{|l|l|}
0.7874 \\
\end{tabular} \\
\hline Har. x Sp. & & $<<0.0001^{*}$ & $0.0102 *$ & $0.0103^{*}$ & $0.0409 *$ & $0.0003^{*}$ & $0.0065^{*}$ & 0.3431 & $0.0357^{*}$ & 0.0099* \\
\hline WPM & & $7.1 \mathrm{a}$ & $79.2 \mathrm{a}$ & $7.6 \mathrm{a}$ & $16.8 \mathrm{a}$ & $40.3 \mathrm{a}$ & $4.3 \mathrm{a}$ & $10.0 \mathrm{a}$ & $0.9 \mathrm{a}$ & $5.2 \mathrm{a}$ \\
\hline ABPD & & $6.6 \mathrm{a}$ & $76.0 \mathrm{~b}$ & $8.0 \mathrm{~b}$ & $13.4 \mathrm{~b}$ & $38.0 \mathrm{~b}$ & $4.8 \mathrm{a}$ & $7.9 \mathrm{~b}$ & $1.2 \mathrm{~b}$ & $5.8 \mathrm{~b}$ \\
\hline
\end{tabular}

$M S$ - mid-summer, LS - late summer, EF - early fall, RSG - reed sweet-grass, CR - common reed, RCG - reed canary grass, TS - tufted sedge, WS - woolyfruit sedge, WPM - wetland plants means, ABPD - agricultural biogas plant digestate; * the factor or combinations of factors have a significant impact; different letters indicate significant differences between digestates $(p<0.05)$.

The harvest time had a significant impact on the analysed properties of digestates $(p<0.05)$, except $\mathrm{pH}$ and TK content (Table 1). For almost every plant species, the TS content was the highest in the third harvest (early fall). In contrast, VS and EC of digestate from the autumn harvest was the smallest. Late summer harvest (the second) resulted in the lowest TN content and highest C:N ratio for every studied species. Due to the highest TP and TKN content, digestates from the third harvest exhibited the greatest fertilizing value.

The quality of digestates differed (except TK) among plant species, from which they were produced ( $p<0.05$; Table 1, Fig 1). The differences were not striking. However, digestate from reed sweet-grass had the best fertilizing properties, because of the highest TKN content (mean $5.0 \%$ TS).

Digestates from anaerobic digestion of wetland plants differed significantly in many ways from residues of the conventional agricultural biogas plant, treating mainly maize silage. They had a higher VS and TC content, clearly higher EC and C:N ratio, but substantially lower TP content and slightly lower $\mathrm{pH}$. We found no statistically significant differences in TS, TKN and TK content (Table 1, Fig. 1). The determined properties of wetland plant digestates indicate high value as fertilizers.

The comparison to quality of liquid digested animal slurries and digestates derived from dedicated crops compiled by Möller and Müller [6] gives slightly different results. Studied digestates were characterised by similar $\mathrm{pH}$ (different researches: 7.3-9.0), and content of TS (1.5-13.2\% ww), TKN (3.1-14.0 \% TS), TC (36.0-45.0 \% TS) and TP (0.6-1.7\% TS). Moreover, they contained significantly more TK (1.9-4.3 \% TS) and VS (63.8-75 \% TS), and had slightly higher C:N ratio (3.0-8.5). 

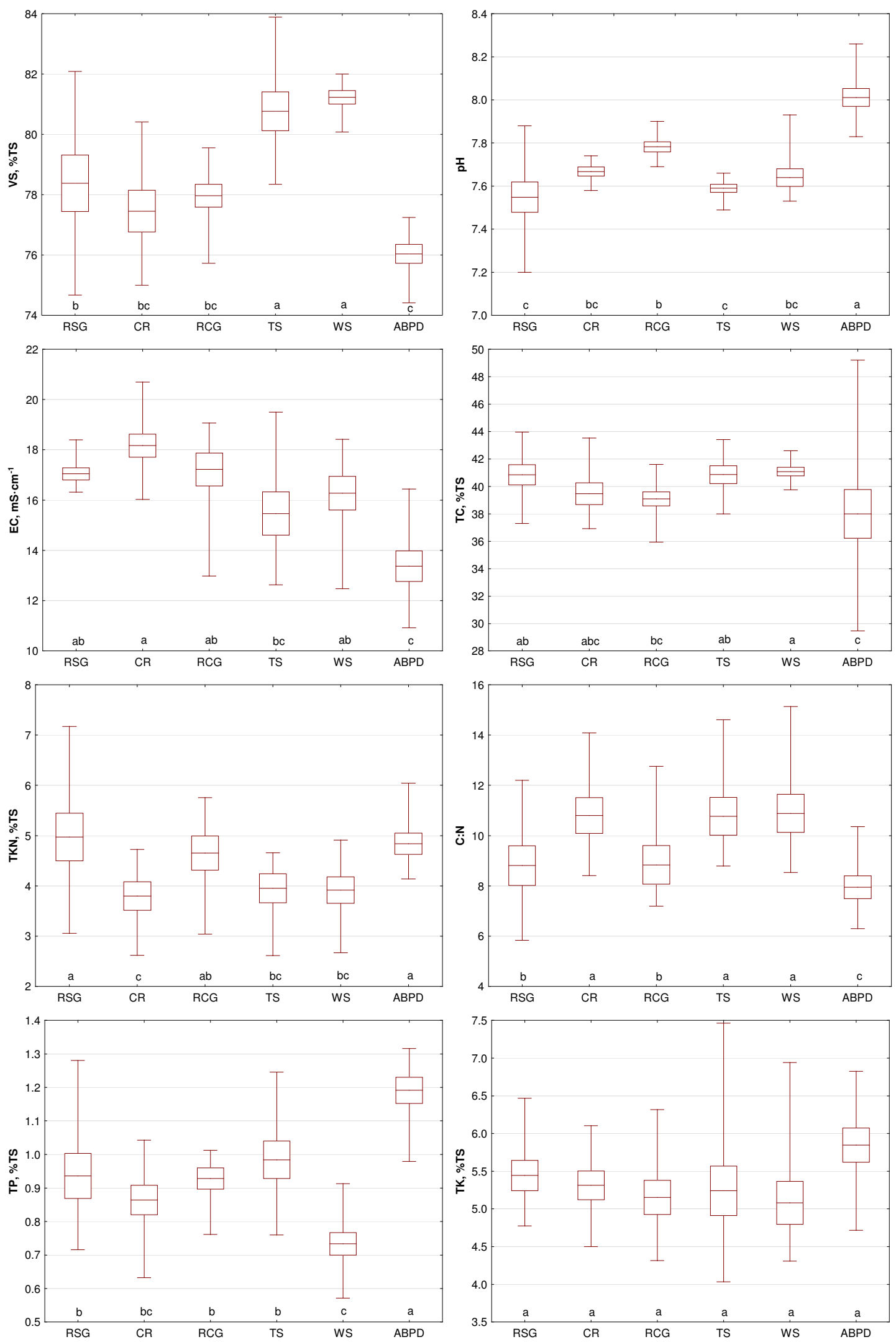

Fig. 1. Box and whiskers plots of chemical and physical properties of studied digestates:

RSG - reed sweet-grass, CR - common reed, RCG - reed canary grass, TS - tufted sedge, WS - woolyfruit sedge, ABPD - agricultural biogas plant digestate; box - mean \pm standard error, whiskers - minimum and maximum values; different letters indicate significant differences between digestates $(p<0.05)$ 


\section{Conclusions}

1. The digestates obtained from anaerobic processing of wetland plants in BMP tests had a higher content of organic matter and total carbon, clearly higher electrical conductivity and C:N ratio, substantially lower content of total phosphorus and slightly lower $\mathrm{pH}$ compared to the residues from the conventional agricultural biogas plant, treating mainly maize silage. No statistically significant differences were noticed in the case of total solids, total nitrogen and total potassium content.

2. Significant differences were found between digestates from different species of wetland plants. Digestate from reed sweet-grass exhibited the best fertilizing properties. The physical and chemical properties of the digestates also differed among harvests. Those produced from biomass mowed in autumn possessed the most significant fertilizing value.

3. Wetland plants should be regarded as an interesting co-substrate in agricultural biogas plants not only because of the adequate amount of biogas that can be obtained from their decomposition, but also because of the high quality of the digestate produced in this process. Digestates from wetland plants due to a high amount of nutrients and organic matter have a high potential as valuable agricultural fertilizers.

\section{Acknowledgements}

This work was financially supported by the Ministry of Science and Higher Education as a part of the project S/WBiIŚ/1/17, Bialystok University of Technology, Bialystok, Poland.

\section{References}

[1] Igliński B., Buczkowski R., Iglińska A., Cichosz M., Piechota G., Kujawski W. Agricultural biogas plants in Poland: Investment process, economical and environmental aspects, biogas potential. Renew. Sustain. Energy Rev, vol. 16, 2012, pp. 4890-4900.

[2] Podkówka Z., Podkówka W., Substraty dla biogazowni rolniczych, Agro Serwis Biznes-Press sp. z o. o., 2010, Warszawa, 36 p. (In Polish).

[3] Fachagentur Nachwachsende Rohstoffe e.V. (FNR), Bioenergy in Germany Facts and Figures 2016, 2017, FNR, 27 p.

[4] Banaszuk P., Kamocki A.K., Zarzecki R. Mowing with invasive machinery can affect chemistry and trophic state of rheophilous mire. Ecol. Eng., vol. 86, 2016, pp. 31-38.

[5] Roj-Rojewski S., Wysocka-Czubaszek A., Czubaszek R., Banaszuk P. Does wetland biomass provide an alternative to maize in biogas generation?, in: K. Mudryk, S. Werle (Eds.), Renewable Energy Sources: Engineering, Technology, Innovation, Springer Proceedings in Energy, Springer, Cham, 2018, pp. 127-137.

[6] Möller K., Müller T. Effects of anaerobic digestion on digestate nutrient availability and crop growth: A review, Eng. Life Sci., vol. 12 (3), 2012, pp. 242-257.

[7] Holm-Nielsen J., Halberg N., Hutingorf S., Seadi A. Joint Biogas Plants. Agricultural advantagescirculation of N, P, and K. Report made for the Danish Energy Agency. Second Edition, 1997.

[8] Chantigny M.H., Angers D.A., Rochette P., Bélanger G., Massé D., Côté D. Gaseous Nitrogen Emissions and Forage Nitrogen Uptake on Soils Fertilized with Raw and Treated Swine Manure. Journal of Environment Quality, vo. 36, 2007, pp. 1864-1872.

[9] Möller K., Stinner W., Deuker A., Leithold G. Effects of different manuring systems with and without biogas digestion on nitrogen cycle and crop yield in mixed organic dairy farming systems, Nutr. Cycl. Agroecosys., vol. 82, 2008, pp. 209-232.

[10] Tambone F., Scaglia B., D’Imporzano G., Schievano A., Orzi V., Salati S., Adani F. Assessing amendment and fertilizing properties of digestates from anaerobic digestion through a comparative study with digested sludge and compost, Chemosphere, vol. 81, 2010, pp. 577-83.

[11] Murphy J., Braun R., Weiland P., Wellinger A. Biogas from crop digestion. IEA Bioenergy, Task 37, [online] [08.03.2018]. Available at: http://task37.ieabioenergy.com/files/datenredaktion/download/publi-task37/Update_Energy_crop_2011.pdf

[12] Drosg B., Fuchs W., Al Seadi T., Madsen M., Linke B., Al Seadi T., Madsen M., Linke B. Nutrient Recovery by Biogas Digestate Processing, 2015, IEA Bioenergy, p. 40. 
[13] Seppälä M., Paavola T., Lehtomäki A., Rintala J. Biogas production from boreal herbaceous grasses - Specific methane yield and methane yield per hectare. Bioresour. Technol., vol. 100, 2009. pp. 2952-2958.

[14] Weiland P. Biomass Digestion in Agriculture: A Successful Pathway for the Energy Production and Waste Treatment in Germany, Eng. Life Sci, vol. 6 (3), 2006, pp. 302-309.

[15] APHA, Standard Methods for Examination of Water and Wastewater, 1998. 